\title{
The risk of being at the top: foot-cropping in the New Zealand cockle Austrovenus stutchburyi
}

\author{
Kim N. Mouritsen* and Robert Poulin \\ Department of Zoology, University of Otago, PO Box 56, Dunedin, New Zealand. \\ *E-mail: kim.mouritsen@stonebow.otago.ac.nz
}

\begin{abstract}
The common phenomenon of sublethal predation in soft-bottom bivalves usually involves nipping of siphons. Here we show that foot cropping, hitherto documented only in Donax spp., is widespread in the New Zealand cockle Austrovenus stutchburyi (Veneridae). Depending on the locality, cropping frequency ranged between 14 and $34 \%$ of cockles, and the average proportion of the foot area cropped ranged between nine and $21 \%$. Estimates of biomass lost to croppers at the time of sampling varied between 235 and $2040 \mathrm{mg} \mathrm{ww} \mathrm{m}^{-2}$. It is emphasized that foot cropping in Austrovenus is likely to affect the population dynamics of the cockles.
\end{abstract}

Sublethal predation is a widespread phenomenon in marine soft-bottom ecosystems, likely due to the high regeneration potential of many benthic invertebrates and the fact that often only a small part of the prey organism is exposed to predators. Invertebrates most often reported to be victims of partial predation include echinoderms, polychaetes and bivalves in which, respectively, arms, tail/head parts and siphons are cropped by a range of predators such as flatfish, crustaceans and shorebirds (de Vlas, 1981; Moreira, 1995; Lawrence \& Vasquez, 1996; Sandberg et al., 1996). Such partial predation often affects the majority of individuals in a prey population, and its importance in terms of trophic energy flow and as mediator of prey population dynamics is far from insignificant (de Vlas, 1981; Zajac, 1985; Bergman et al., 1988; Lawrence \& Vasquez, 1996; de Goeij et al., 2001).

In bivalves, siphons are not the only part that is susceptible to cropping. Recently, Salas et al. (2001) demonstrated that intertidal populations of Donax spp. (Donacidae) were exposed to foot cropping, presumably by crabs. This unusual kind of partial predation may be particularly detrimental, as it will leave the bivalve on the sediment surface unable to rebury and fully exposed to predators and environmental stress during low tide. Here, we present evidence that foot cropping is not a phenomenon unique to Donax species by demonstrating its occurrence in the New Zealand cockle Austrovenus stutchburyi (Gray).

Cockles were collected in Otago Harbour (New Zealand, South Island) during the austral autumn (March-April 2002) from the lower mid-intertidal of five sand flats differing with respect to substrate characteristics and exposure to prevailing winds (Table 1). At each flat, cockle density was estimated from the number present in five $314 \mathrm{~cm}^{-2}$ core samples taken along a $25 \mathrm{~m}$ transect parallel to the water line. A random subsample of these cockles was returned to the laboratory and after measurements of shell length, the cockles were opened and the foot was removed by cutting along the well-defined interface between the foot tissue and the gonad-visceral mass. The foot was placed on graph paper so that it formed a right-angled triangle, with the cutting edge and the front of the foot making up the two sides of the right angle and the outer foot rim as the hypotenuse. The outline of the foot was then drawn on the paper. Incidence of foot cropping was easily identified as abrupt depressions along the otherwise straight foot-rim (Figure 1), and the proportion of the foot cropped was estimated from the relationship between the projected foot area lost to cropping and the projected uncropped/ intact foot area (obtained by extra- or interpolation of undamaged parts of the foot rim).

The data presented in Table 1 show that foot cropping is ubiquitous in the population of cockles in Otago Harbour with a grand mean of $24 \%$ of the cockles cropped and $13 \%$ of the foot tissue lost to the croppers at the time of collection. Although cropping seemed most frequent in the more sheltered areas (Table 1), no statistically significant difference could be demonstrated between habitats in either frequency of cropping (Chisquare test, $\left.\chi_{4}^{2}=6.81, P=0.15\right)$ or the proportion of the foot

Table 1. Habitat characteristics and density $(\mathcal{N}=5)$, shell size and foot-cropping measures of Austovenus stutchburyi from five tidal sand flats in Otago Harbour. Values are means ( $\pm S D$; [range $]$ ).

\begin{tabular}{|c|c|c|c|c|c|c|c|}
\hline Site & Habitat characteristics & $\begin{array}{l}\text { Cockle } \\
\text { density } \\
\left(\text { no. } \mathrm{m}^{-2}\right)\end{array}$ & $\begin{array}{l}\text { Cockle } \\
\text { length } \\
(\mathrm{mm})\end{array}$ & $\begin{array}{l}\text { Cropping } \\
\text { frequency } \\
(\%)\end{array}$ & $\mathrm{N}$ & $\begin{array}{l}\text { Proportion } \\
\text { of foot } \\
\text { cropped }(\%)\end{array}$ & $\begin{array}{l}\text { Biomass } \\
\text { cropped } \\
\left(\mathrm{mg} \mathrm{ww} \mathrm{m}^{-2}\right)\end{array}$ \\
\hline Oyster Bay & Sheltered; silty sand and gravel & $961.3 \pm 126.1$ & $25.5 \pm 2.4$ & 34.3 & 35 & $21.3[5.4-54.2]$ & 2040 \\
\hline Company Bay & Sheltered; silty sand & $623.9 \pm 160.1$ & $30.9 \pm 2.4$ & 32.5 & 40 & $11.5[4.2-41.7]$ & 1282 \\
\hline Otakou & Semi-exposed; fine sand & $401.1 \pm 94.4$ & $33.9 \pm 3.8$ & 22.2 & 36 & $13.2[2.1-30.6]$ & 815 \\
\hline Waipuna Bay & $\begin{array}{l}\text { Exposed; mixed sea grass-bed } \\
\text { and fine sand }\end{array}$ & $267.4 \pm 53.3$ & $31.2 \pm 3.5$ & 17.5 & 40 & $9.1[4.8-20.4]$ & 240 \\
\hline Gills Corner & Exposed; fine sand & $369.2 \pm 91.7$ & $28.3 \pm 2.1$ & 14.3 & 42 & $10.5[4.5-17.8]$ & 235 \\
\hline
\end{tabular}




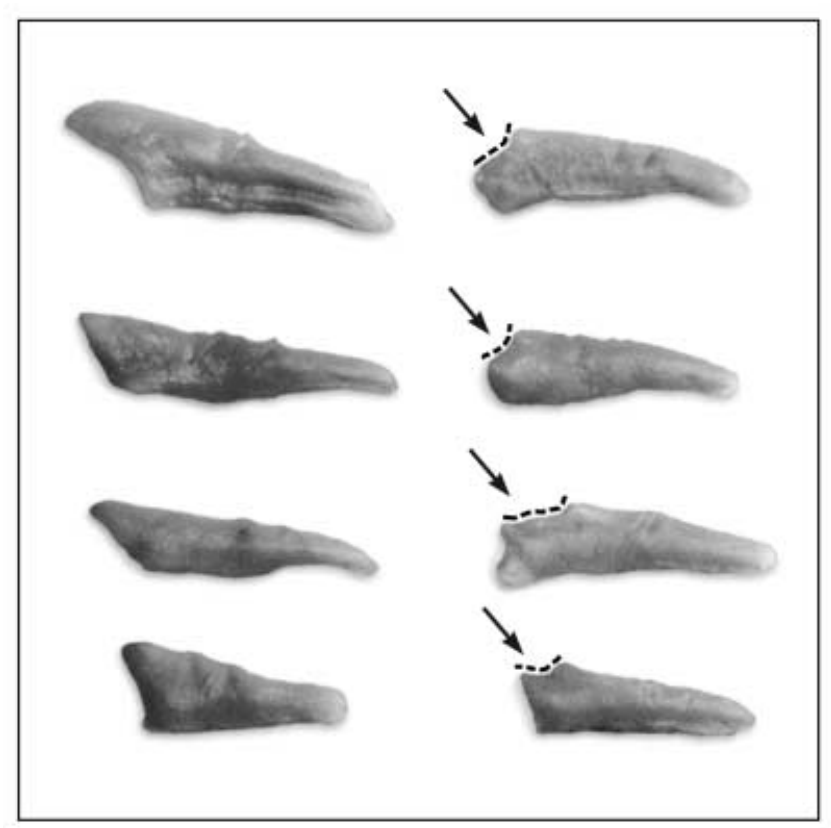

Figure 1. Undamaged (left column) and cropped (right, arrows and broken line) feet from cockles collected on the Otakou tidal flat. Most frequently, incidence of cropping involved the tip of the foot (as shown), but any part of the outer foot rim could be attacked.

cropped (Kruskal-Wallis test, $\chi^{2}{ }_{4}=5.32, P=0.26$ ). Moreover, cropped and un-cropped cockles did not differ regarding mean shell length at any of the sites (Student's $t$-test, all $t 1.62$, all $P$ 0.11), suggesting that the risk of cropping is evenly distributed among the different size/age-classes collected. However, both cockle density and size differed among sites (respectively, oneway ANOVA, $F_{4,20}=31.01, P<0.0005$ and Kruskal-Wallis test, $\left.\chi_{4}^{2}=93.41, P<0.0005\right)$, and there was a significant positive relationship between frequency of cropping and cockle density across all 25 core samples from the five sites pooled (respectively, arcsin- and ln-transformed data; $\left.r^{2}=0.66, P<0.0005\right)$. Together, this means that the amount of biomass lost to croppers per square metre differs among sites. Based on a significant linear regression between foot wet weight $(F W W, \mathrm{mg})$ and shell length (SL, mm) obtained from a sample of uncropped cockles $\left(F W W=4.80 S L-93.35 ; F_{1,136}=201.8, P<0.0005\right)$, and the density, size and cropping data presented in Table 1 , the average amount of cockle biomass ( $\mathrm{mg}$ wet weight) lost to croppers per $\mathrm{m}^{2}$ can be estimated for each site. These estimates suggest that foot cropping in terms of biomass removed is most important (up to nine-fold) in the more sheltered areas (Table 1). It should be emphasized that because the bivalves are able to regenerate their foot, the figures seriously underestimate the amount of biomass cropped annually.

The identity of the foot-croppers is presently unknown. However, flatfish known for their cropping habits (e.g. Ansell \& Gibson, 1990; Ansell et al., 1999) are common on the investigated sand flats during high tide, and the observation of a wrasse (Notolabrus sp.) removing a cockle from the sediment by its foot, suggest that bottom-feeding fish in general could be responsible. The character of the wounds found on the cropped cockle feet also points at fish rather than other predators, e.g. crabs (see Salas et al., 2001). Regardless of the identity of the croppers, the widespread occurrence of foot cropping in cockles raises questions about what factors promote this unusual form of non-lethal predation. Clearly, in order to expose the foot to epibenthic predators, the bivalve has to leave the substrate in which it is buried, and from all a priori expectations this is maladaptive behaviour. Available information suggests that both bioturbation and parasites are important factors causing cockles to surface, and that the relative importance of these factors varies among the five sites investigated (Thomas \& Poulin, 1998; K.N. Mouritsen, unpublished data).

This cascade of events involving disturbance/parasites, surfacing and foot cropping, is likely to have implications for the cockles' population dynamics. Cropped cockles are unable to bury before their foot has regenerated, and in newly cropped individuals this may take up to eight weeks (K.N. Mouritsen, unpublished observations). During this time the surfaced cockles will be exposed to severe thermal and desiccation stress and a substantially higher predation risk, together elevating the overall mortality rate (Thomas \& Poulin, 1998; K.N. Mouritsen, unpublished data).

The work was supported by the Danish Natural Science Research Council, The Carlsberg Foundation (K.N. Mouritsen), and the Marsden Fund, New Zealand.

\section{REFERENCES}

Ansell, A.D. \& Gibson, R.N., 1990. Patterns of feeding and movement of juvenile flatfishes on an open sandy beach. In Trophic relationships in the marine environment (ed. M. Barnes and R.N. Gibson), pp. 191-207. Aberdeen: Aberdeen University Press.

Ansell, A.D., Harvey, R. \& Günther, C.-P., 1999. Recovery from siphon damage in Donax vittatus (Da Costa) (Bivalvia: Donacidae). Fournal of Molluscan Studies, 65, 223-232.

Bergman, M.J.N., Veer, H.W. van der \& Karczmarski, L., 1988. Impact of tail-nipping on mortality, growth and reproduction of Arenicola marina. Netherlands fournal of Sea Research, 22, 83-90.

Goeij, P. de, Luttikhuizen, P.C., Meer, J. van der \& Piersma, T., 2001. Facilitation on an intertidal mudflat: the effect of siphon nipping by flatfish on burying depth of the bivalve Macoma balthica. Oecologia, 126, 500-506.

Lawrence, J.M. \& Vasquez, J., 1996. The effect of sublethal predation on the biology of echinoderms. Oceanologica Acta, 19, $431-440$.

Moreira, F., 1995. Diet of black-headed gulls Larus ridibundus on emerged intertidal areas in the Tagus estuary (Portugal): predation or grazing? Fournal of Avian Biology, 26, 277-282.

Salas, C., Tirado, C. \& Manjón-Cabeza, M.E., 2001. Sublethal foot-predation on Donacidae (Mollusca: Bivalvia). Fournal of Sea Research, 46, 43-56.

Sandberg, E., Tallqvist, M. \& Bonsdorff, E., 1996. The effect of reduced oxygen content on predation and siphon cropping by the brown shrimp, Crangon crangon. Marine Ecology, 17, 411-423.

Thomas, F. \& Poulin, R., 1998. Manipulation of a mollusc by a trophically transmitted parasite: convergent evolution or phylogenetic inheritance? Parasitology, 116, 431-436.

Vlas, J. de, 1981. On cropping and being cropped: the regeneration of body parts by benthic organisms. In Feeding and survival strategies of estuarine organisms (ed. N.V. Jones and W.J. Wolff), pp. 173-177. New York: Plenum Press.

Zajac, R.N., 1985. The effect of sublethal predation on reproduction in the spionid polychaete Polydora ligni Webster. Fournal of Experimental Marine Biology and Ecology, 88, 1-19.

Submitted 19 July 2002. Accepted 2 March 2003. 